\title{
The Influence of Satisfaction on Dimension of Service Quality toward Loyality of Savings Customers at PT. Bank Bukopin, Tbk. Branch of Padang
}

\author{
Yusmardi ${ }^{1}$, Susi Evanita ${ }^{2}$, Idris ${ }^{3}$ \\ ${ }_{1}^{1}$ Universitas Negeri Padang, Padang, Indonesia, $\square$ adhy.alkindi@gmail.com \\ ${ }^{2}$ Universitas Negeri Padang, Padang, Indonesia, $\square$ susievanita@gmail.com \\ ${ }^{3}$ Universitas Negeri Padang, Padang, Indonesia, $\square$ idris_unp@yahoo.co.id
}

\begin{abstract}
This research aimed to find the influence of satisfaction on the quality dimension for the customer loyality at PT. Bank Bukopin, Tbk. Branch of Padang. This research aimed to find:1) the influence of satisfaction on tangibles for the customer loyality, 2) the influence of satisfaction on reliability for the customer loyality, 3) the influence of satisfaction on responsiviness for the customer loyality, 4) the influence of satisfaction on assurance for the customer loyalty, 5) the influence of satisfaction on empathy for the customer loyality. This research is causative study with a population totally are 21.528 respondents. The withdraw of the sampling method is using Accidental Sampling method, with total of sample are 156 respondents. Primary data was collected through polls using Likert Scale model that has been tested validity and reliability. Data analysis technique that was used is Multiple Regression Analysis. The results of research are:1) there is a positive and significant impact of satisfaction on the tangibles for the customer loyality, 2) there is a positive and significant effect of satisfaction on the reliability for the customer loyality, 3) the satisfaction on the responsiviness has no significant effect for the customer loyalty, 4) the satisfaction on the assurance has no significant effect for the customer loyalty, 5) the satisfaction on the empathy has no significant effect for customers loyalty at PT Bank Bukopin, Tbk. Branch of Padang.
\end{abstract}

Keywords: loyality, satisfaction, dimension of service quality

\section{Introduction}

The progress of science, technology and information systems is growing rapidly and affecting all fields, especially the advancement of the banking service sector. Competition in the banking sector in the last few years has been increasingly stringent. Competition between banks is increasingly tight in an effort to attract customers, retain loyal customers and maintain existing market share. Along with the increasing competition in the business world today, it is increasingly difficult for companies to be able to maintain customer loyalty so as not to move to another company.

Customer loyalty has an important role for the survival of a bank. Loyalty can be achieved if there is customer satisfaction with the quality of banking services. Customer satisfaction as a function of the difference between perceived performance and expectations. High service quality will have an impact on customer loyalty. Loyalty is an important factor for a company to survive and the increasingly fierce business competition. Loyalty is needed by a bank because it will show a good and positive sign for the product or service offered.

Banks are business entities that collect funds from the public and channel funds in the form of loans and conduct financial transactions with the aim of public welfare. (Kasmir,2010) states that the main objective in the marketing strategy run by banks is to increase the amount of customer funds and accounts, both in quantity and quality. Quantitatively, the number of customers increases over time can be seen from the increase in the number of savings accounts, while in quality means that the customers obtained are productive customers who can provide profits for the bank.

The concept of service quality has become the dominant factor in the success of a company. In principle, every company must be able to satisfy and retain customers. The loyalty is created by the satisfaction, and satisfaction is created from the results of good quality bank services. 
Customer satisfaction with service quality can be measured from the dimensions of service quality, which according to Walker and Mullins in (Hidayat, 2016), Dimensions of Service Quality is tangibles, reliability, responsiveness, assurance and empathy. Of the five dimensions of quality, it can be seen how far the influence of satisfaction on service on customer loyalty.

The development of banking in Indonesia is increasingly advanced and rapid. The following are 11 (eleven) banks that have won the main award as banks with the highest level of satisfaction, loyalty and customer attachments at the Satisfaction, "Loyalty and Engaging Awards 2018" event in Jakarta, Thursday 17 May 2018. As for the order of eleven banks can be seen in Table 1.1 below:

Table 1 Survey of the Best Satisfaction, Loyality and Engagement (SLE) Infobank and Marketing Research Indonesia (MRI) 2018

\begin{tabular}{cll}
\hline Rangking & Name of Bank & \multicolumn{1}{c}{$\begin{array}{c}\text { Group of } \\
\text { Bank }\end{array}$} \\
\hline 1 & Bank BCA & BUKU 4 \\
\hline 2 & Bank BNI & BUKU 4 \\
\hline 3 & Bank Danamon & BUKU 4 \\
\hline 4 & Bank Bukopin & BUKU 3 \\
\hline 5 & Bank OCBC NISP & BUKU 3 \\
\hline 6 & Bank Permata & BUKU 3 \\
\hline 7 & Bank BSM & Syariah Bank \\
\hline 8 & Bank Muamalat & Syariah Bank \\
\hline 9 & Bank Sumut & BPD \\
\hline 10 & Bank Jateng & BPD \\
\hline Source : Infobank 2018 ( www.infobanknews.com )
\end{tabular}

From Table 1, it can be seen that based on the results of a survey by Infobank magazine with Marketing Research Indonesia (MRI), we can see that Bank Bukopin won a large ranking of 4 (four) under Bank BCA, Bank BNI and Bank Danamon. This BUKU stands for Commercial Bank Business Activities which is the group level of a banking company based on its core capital. BUKU 1 is a Bank with core capital of under Rp 1 trillion, BUKU 2 is a Bank with core capital of between Rp 1 trillion Rp 5 trillion, BUKU 3 is a Bank with core capital of Rp 5 trillion - Rp 30 trillion and BUKU Bank 4 is a bank with core capital above Rp. 30 Trillion.

The results of the survey on Table.1 contribute and are important in the study because to determine the extent of the loyalty achievements of the PT. Bank Bukopin, Tbk. So from Table 1 it can be seen that Bukopin Bank must continue to strive to increase customer loyalty by increasing customer satisfaction with service quality. Bank Bukopin must continue to strive to be ranked better among the banks in Indonesia.

The loyal customers will usually be active in routine transactions at the bank, whereas customers who are less loyal, rarely do routine transactions, even those with account status passive. Passive accounts are customer savings accounts that do not carry out routine transactions for 6 (six) months in a row, so that a passive account results in customers being unable to conduct financial transactions.

Following Table 2 shows a comparison of the composition of passive customer accounts with savings active customer accounts. 
Table 2 Comparison Data of the Composition of Passive and Active Customer Savings Accounts at PT. Bank Bukopin, Tbk. Branch of Padang

\begin{tabular}{cccccc}
\hline $\begin{array}{c}\text { Year } \\
(\mathbf{3 1} \mathbf{D e c})\end{array}$ & $\begin{array}{c}\text { Passive } \\
\text { account }\end{array}$ & $\begin{array}{c}\text { Composition } \\
\mathbf{( \% )}\end{array}$ & $\begin{array}{c}\text { Active } \\
\text { Account }\end{array}$ & $\begin{array}{c}\text { Composition } \\
\mathbf{( \% )}\end{array}$ & $\begin{array}{c}\text { Total } \\
\text { Account }\end{array}$ \\
\hline 2009 & 2.235 & 25,84 & 6.413 & 74,16 & 8.648 \\
\hline 2010 & 2.790 & 30,08 & 6.486 & 69,92 & 9.276 \\
\hline 2011 & 3.654 & 35,82 & 6.546 & 64,18 & 10.200 \\
\hline 2012 & 5.475 & 39,54 & 8.373 & 60,46 & 13.848 \\
\hline 2013 & 8.283 & 51,38 & 7.839 & 48,62 & 16.122 \\
\hline 2014 & 10.438 & 56,99 & 7.879 & 43,01 & 18.317 \\
\hline 2015 & 12.742 & 59,23 & 8.786 & 40,77 & 21.528 \\
\hline
\end{tabular}

Source: Bank Bukopin Branch of Padang in 2016

Based on Table 2 above, it can be seen that passive accounts increase from year to year and the composition of passive accounts is greater than active accounts, this indicates that there is a decrease in loyalty of savings customers at PT. Bank Bukopin, Tbk. Branch of Padang. The author suspects that the possible factors affecting the decrease in customer loyalty are satisfaction with the quality of service at PT. Bank Bukopin, Tbk. Branch of Padang.

Apart from the large number of passive accounts, the Bank Bukopin Branch of Padang also has fundamental limitations for the types of physical facilities (tangibles) provided by the bank, such as the physical condition of the building that has been around for a long time (1985) which needs to be renovated. In addition to the condition of the parking lot that is not sufficient and narrow enough to accommodate customers' vehicles that come, inadequate seating facilities so that some customers are still standing while waiting, this often happens at the beginning of each month, because many customers, especially retired savings (tabungan pensiun) customers come early in the month to get a salary. This condition causes a gap between customer expectations and services received, thus giving rise to feelings of disappointment and dissatisfaction with customers.

In terms of Bank Bukopin's reliability, it was found that ATM features were not yet sophisticated, still using Indonesian, while English was not yet available, there were not many ATM machine conditions, ATMs that were not 24 hours, ATM cash withdrawals such as banks- other private banks, and the condition of the network system that has not been stable, for example there are some ATMs that are often offline due to non-renewed machines and E-Banking facilities such as internet banking, mobile banking, sms banking which are still not fast and often network problems. This was felt by Bank Bukopin's customers in Padang Branch. If this is allowed to continue, it will have an impact on the transfer of customers to other banks, customers will be less satisfied and cause a decrease in customer loyalty.

In terms of responsiveness in the field it was found that tellers and CS were still lacking in serving customers, especially at the beginning of the month because of the overcrowding of customers. So customers have to wait and queue for long. So that customers become less satisfied. This needs to be considered by the management of Bank Bukopin because it will have an impact on decreasing the loyalty of savings customers at PT. Bank Bukopin, Tbk Branch of Padang.

From the phenomenon found in the field, which is still incomplete, the form of service provided by the Padang Branch of Bank Bukopin will certainly affect the number of customers loyal to the bank. Thus it can be said that satisfaction with service quality will affect the loyalty of savings customers at Bank Bukopin. The research at Bank Bukopin is customer satisfaction on quality dimensions such as customer satisfaction with tangible, customer satisfaction on reliability, customer satisfaction on responsiveness, customer satisfaction on guarantees and customer satisfaction on empathy for customer loyalty at PT. Bank Bukopin, Tbk. Padang Branch. Based on the description above, the author focuses more on the influence of satisfaction on the dimensions of service quality on the loyalty of savings customers at PT. Bank Bukopin, Tbk. Branch of Padang. So from the 
background above the author is interested in giving the title of this research, "The Influence of Satisfaction on the Dimensions of Service Quality Toward Loyality of Savings Customers at PT. Bank Bukopin, Tbk. Branch of Padang."

This research aimed to find the influence of satisfaction on the quality dimension for the customer loyality at PT. Bank Bukopin, Tbk. Branch of Padang. This research aimed to find:1) the influence of satisfaction on tangibles for the customer loyality, 2) the influence of satisfaction on reliability for the customer loyality, 3) the influence of satisfaction on responsiviness for the customer loyality, 4) the influence of satisfaction on assurance for the customer loyalty, 5) the influence of satisfaction on empathy for the customer loyality. The significance of this research is to find out how far the influence of satisfaction on service quality affects the loyalty that exists at PT. Bank Bukopin, Tbk and the importance of increasing customer loyalty in order to improve the image and progress of PT. Bank Bukopin, Tbk in the future.

\section{Loyalty}

The definition of loyalty according to Oliver in (Widodo, 2018) is: Customer loyality is deeply held commitment to rebuy or repatronize a preferred product or service consistenly in the future, despite situational influences and marketing efforts having the potential to cause switching behavior. The Meaning of loyalty according to Kotler and Keller in (Widodo, 2018), loyalty is a strong commitment to buy or subscribe to certain products or services in the future despite the influence of the situation and marketing efforts that have the potential to cause behavioral shifts. While loyalty As according to Rangkuti in (Asmawati, 2018) states loyalty is a combination of intellectual and emotional processes, between customers and companies. Customer loyalty is elusive and intangible.

According to Kotler, Bowen and Makens in (Laškarin, 2013) customer loyalty is defined as the possibility of customers buying back and their willingness to become partners for the company.

Types of Loyalty according to Griffin in (Agrawal, Gaur, \& Narayanan, 2013; Khan, 2016), divide loyalty in four types, namely: a. Without loyalty, based on certain reasons, customers may not develop loyalty to certain products or services. Companies must avoid targeting buyers of this type because they will never be loyal customers, they only contribute little to the company's finances. $b$. Weak loyalty (spurious loyalty), customers who have weak loyalty to the company, they will buy because of habits. Low interest combined with high purchasing results in weak loyalty. This type of buyer feels a certain level of satisfaction with the company or at least there is no real satisfaction. This type of loyalty is most common in frequently purchased products or frequently visited stores. c. Latent loyalty, a relatively high reference level combined with a low repurchase rate, shows hidden loyalty. If the customer has hidden loyalty, then determining repeat purchases is the influence of the situation and not the attitude. By understanding the situation factors contributing to hidden loyalty, companies can use strategies to overcome them. d. Premium loyalty, is the most enhanced loyalty. This type of loyalty occurs when there is a high level of interest and a high rate of repeat purchases. This is the preferred loyalty for all customers in each company. At the highest level of preference makes people proud of finding and using certain products and happy to share their knowledge with colleagues and family.

The level of customer loyalty according to Griffin in (Agrawal et al., 2013; Khan, 2016), customer loyalty is divided into six stages, namely suspect, prospect, customer, clients, advocates and partners. These stages are explained as follows:

1. Suspect, includes everyone believed to be buying (needing) company goods or services.

2. Prospect, are people who have the need for certain services, and have the ability to buy them. At this stage, even though they have not made a purchase, they already know the existence of the company and services offered through recommendations from other parties (word of mouth).

3. Customer, at this stage, the customer has made a transaction with the company, but does not have positive feelings for the company, loyalty at this stage has not been seen.

4. Clients, including all customers who have purchased goods / services needed for a long time and they already have the nature of retention. 
5. Advocates, at this stage, Clients actively supports the company by giving recommendations to other people to buy goods / services in the company.

6. Partners, at this stage has become a strong and mutually beneficial relationship between the company and the customer, at this stage customers also dare to reject goods / services from the company.

The factors that influence loyalty according to Marconi in (Abror, Evanita, \& Hidayat, 2012), are: value (price and quality, image, comfort and convenience to get a brand, customer satisfaction, service and guarantee (guarantee) provided by the brand. according to Ali Hasan in (Setiaji, 2014), the factors that influence customer loyalty are as follows: (a) customer satisfaction, (b) service quality, (c) brand image, (d) customer value, (e) trust, ( f) customer relationship, (g) service waiting time (h) reliability / dependability.

Kotler in (Widodo, 2018), the factors that influence loyalty are as follows:

1. Customer satisfaction, customer satisfaction as a feeling of likes and sorrows for a product after he compared the achievements of these products with expectations.

2. Service quality, service quality has an influence on customer loyalty. High quality products will create customer loyalty if the price offered competes.

3. Image, image is a set of beliefs, ideas and impressions that someone has towards an object. Products / services that have a high image cause people will not think long to buy and use it and can be someone who will be loyal to the service or product.

4. Moving hurdles, the greater the barriers to switching customers will be more loyal to the company.

Based on the theory stated above it can be concluded that customer loyalty is the commitment and loyalty of customers in using a product repeatedly, actively and voluntarily recommending the use of bank services to other parties. Based on the description above, the factors that influence customer loyalty are fulfilled customer satisfaction, quality service, company reputation (image), customer value and obstacles to changing customers. The bank's good name will be created from the customer's assessment of the quality of bank services. If Bank Bukopin's service quality is good, loyal customers will be created.

\section{Customer Satisfaction}

Satisfaction according to Kotler in (Kasmir, 2014) is the assessment of customers for the use of goods or services compared to expectations before their use. So, the level of satisfaction is a function of the differences in perceived performance (perceived performance) and expectations (expectations). (Kotler and Keller, 2013) also say satisfaction (satisfaction) is a feeling of pleasure or disappointment someone who arises because of comparing the perceived performance of the product (or result) to their expectations.

In the last decade a lot of models have been developed to explain customer satisfaction and service quality, one of which is the disconfirmation theory. According to Johnston (1995) in (Abror, Evanita, \& Hidayat, 2012) disconfirmation theory shows that satisfaction is closely related to the experience of disconfirmation, where disconfirmation depends on the initial expectations of a customer. This theory is very similar to the service quality model, where service quality is the result of customer perceptions of the services it receives. If consumer perceptions are in accordance with consumer expectations, it is expected that consumers or customers will be satisfied and vice versa if not fulfilled, consumers will feel dissatisfied.

Kotler and Keller (2009) in (Abror, Evanita, \& Hidayat, 2012) say that customer or customer satisfaction is determined by two things, first is pre-purchase expectations, that is, beliefs about the anticipated performance of a product / service and the second is the difference between purchase expectations and perceptions of after-purchase. This process will confirm the customer's initial expectations. In measuring customer satisfaction can be used 4 ways, namely, a system of complaints and suggestions, direct surveys / measurements, stealth shopping and customer analysis is lost. If the consumer is satisfied, he will make a repurchase or at least recommend the product to others, but if 
there is dissatisfaction, the consumer might move to another product. This is what causes why customer satisfaction needs to be examined periodically because high levels of satisfaction will create an emotional bond with a particular brand or company, and this creates high customer loyalty. Satisfaction measurement is expected to help banking companies improve and maintain their competitive advantage, especially performance excellence with profit.

Whereas according to (Herry A. Buchory and H. Djaslim Saladin, 2010) satisfaction is a feeling of pleasure or disappointment someone who comes from a comparison between his impression of the performance (or results) of a product and its expectations. Satisfaction according to (Sofjan,2012), customer satisfaction is the main driver for customer retention and loyalty.

As according to Rangkuti in (Asmawati, 2018) there are eight factors that influence consumer satisfaction. These factors are as follows: (a) value, (b) competitiveness (c) customer perception, (d) price, (e) image, (f) service phase, (g) service moment (service situation), (h) the level of customer interest.

The main objective of the marketing strategy in banks is to increase the number of customers, both in quantity and quality. Quantitatively, the number of customers increases significantly from time to time, whereas in quality means customers who are able to become productive customers are able to provide profits for the bank. To achieve this goal, it can be done in various ways and one of them is through providing customer satisfaction. The main objective of the marketing strategy carried out in banks is to increase the number of customers, both in quantity and quality. Quantitatively, the number of customers increases significantly from time to time, whereas in quality means customers who are able to become productive customers are able to provide profits for the bank. To achieve this goal, can be done in various ways and one of them is through providing customer satisfaction.

Customer satisfaction becomes very valuable for banks or companies that need to be best served. In practice, if the customer is satisfied with the services provided by the bank, there are two benefits received by the bank. First, The old customer will be maintained (not run to another bank) or in other words the customer is loyal to the bank. This is the same as stated by Derek and Rao in (Kasmir,2014) who say overall customer satisfaction will lead to customer loyalty. Second, Old customer satisfaction will spread to new customers in various ways, so as to increase the number of customers. As stated by Richens in (Kasmir,2014) that customer satisfaction by providing recommendations or telling about the pleasant experience and advertising from mouth to mouth. This means that the customer will quickly spread to other customers and potentially add new customers.

According to (Kasmir,2014), customer satisfaction given by banks will have a very broad impact on increasing bank profits. Or in other words, if the customer is satisfied with the purchase of bank services, the customer will:

1. Loyal to the bank, meaning that it is unlikely that the customer will move to another bank and will remain loyal to be the customer of the bank concerned.

2. Repeating product purchases, meaning satisfaction with purchasing bank services will cause customers to repurchase services offered repeatedly.

3. Buy another product in the same bank, in this case the customer will expand the type of services offered so that the customer's purchases become more diverse in one bank.

4. Providing free promotions by word of mouth. This is what the bank wants because the talk of the quality of bank services to other customers will be proof of the quality of services offered.

To achieve the objectives as above, or in other words customer satisfaction continues to increase, it is necessary to do the following:

Paying attention to the quality of service from bank staff who serve customers with friendliness, courtesy and fast and efficient service. Bank staff here starts from the lowest staff to the highest leader in the bank.

1. Approach and proximity factors to interact with the bank staff. Customers are treated like old friends, so that intimacy and comfort arise when dealing with the bank.

2. The price offered, the price here for the bank, which is either deposit interest, or loan interest or profit sharing and administrative fees offered competitively with other banks. 
3. The convenience and security of the bank's location, as a place of transaction, in this case the customer always feels that there is comfort both outside the bank and inside the bank.

4. Ease of obtaining bank products. This means that the types of products offered are complete and do not require convoluted procedures or burdensome requirements such as in the case of credit applications.

5. Handling complaints or complaints. That is, any complaints or complaints made by customers must be responded to and dealt with quickly and appropriately.

6. The completeness and usefulness of the product includes the completeness of the facilities and products offered, for example the availability of ATM machines in various strategic locations.

7. Attention to customers in the future, especially for after-sales services.

So from the description of the theory above, it can be concluded that customer satisfaction is a person's feeling of pleasure for the product's performance in accordance with its expectations in meeting the needs and desires of the customer. So Bank Bukopin's customer satisfaction can be created if the bank can meet the needs and desires of customers that are in line with their expectations.

\section{Service Quality}

Service quality according to Kotler and Keller in (Widodo, 2018) quality is the totality of features and characteristics of a product or service that depends on the ability to satisfy expressed or implied needs. According to (Tjiptono,2010) is a dynamic condition that influences products, services, people, processes and environments that meet or exceed expectations. So the definition of service quality can be interpreted as an effort to meet the needs and desires of consumers and the accuracy of delivery in offsetting consumer expectations. While quality according to (Nursya'bani,2010) quality is the overall characteristics and characteristics of a product or service concerning the ability to meet predetermined or latent needs.

According Parasuraman, et.al in (Tjiptono,2010), quality services are needed because:

1. Service quality is one of the best ways to create value for consumers.

2. Service quality is the key to real differences and that distinguishes our products from competing products.

3. Quality of service greatly influences customer mobility.

4. Quality of service always benefits the company.

Service quality contributes significantly to the creation of differentiation, positioning and competitive strategies for every marketing organization, both manufacturing companies and service providers. The measurement perspective for quality bias is grouped into two types: internal and external. Quality based on internal perspective means Zero defect (doing it right the first time), while external perspective understands quality based on customer perception, customer expectations, customer satisfaction, customer attitude and customer delight.

The dimensions of service quality according to Parasuraman, in Zeithaml and Berry in Walker and Mullins in (Widodo, 2018), Dimensions of Service Quality are:

1. Tangibles (appearance of physical facilities, equipment, personnel, and communication materials).

2. Reliability (ability to perform the promised service dependably and accurately).

3. Responsiveness (willingness to help customers and provide prompt service).

4. Assurance (knowledge and courtesy of employees and their ability to convey trust and confidence).

5. Empathy (caring, individualized attention the firm provides its customers).

In providing the best service, the quality aspect is the most important thing and should be taken into account because quality service is one of the best ways to create customer expected values, where quality service is the key to differentiating a company from another company. Customers will be more like a unique product with excellent service. 


\section{Influence and Relationship of Satisfaction on Service Quality to Customer Loyalty.}

According to (Lupiyoadi, 2010), arguing that the quality of employee services to customers has an asymmetrical effect on customer satisfaction, where poor service has a greater impact on customer satisfaction than services that are categorized as good. (Parasuraman, 2010), said that service quality with customer satisfaction where increasing (increasingly positive) service quality is used as a reflection of increasing customer satisfaction. The results of the research of (Huda and Wahyuni ,2013) show that there is a positive and significant relationship between service quality and customer loyalty. (Kartika et al, 2014) stated that good service quality will result in high customer satisfaction that can increase customer loyalty. In taking policies to increase loyalty, service quality needs to be considered because this variable has a positive and significant effect on loyalty.

So based on the description of the theory above, it can be concluded that service quality is the whole of product characteristics that can meet the needs and desires of customers. From the description above, it can be concluded that the effect of service quality on customer loyalty is positive and significant. Customers who are satisfied with the quality of bank services will create loyal customers. Loyal customers will certainly have a positive impact on the survival of the bank in the future.

\section{Conceptual Framework}

Conceptually it can be described about the effect of satisfaction on the dimensions of service quality on customer loyalty as shown in Figure 1 below:

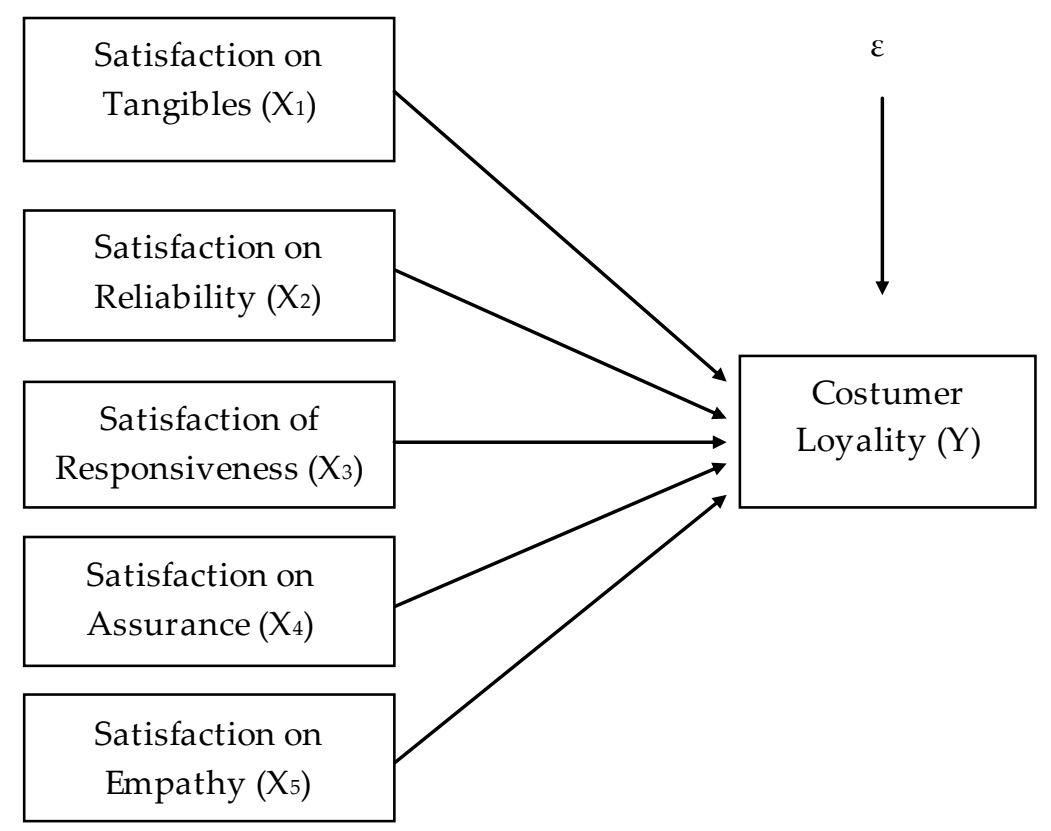

Figure 1 Conceptual Framework

\section{Hypothesis}

1. Satisfaction on tangibles has a significant effect on the loyalty of savings customers at PT. Bank Bukopin, Tbk. Branch of Padang.

2. Satisfaction on reliability has a significant effect on customer loyalty savings at PT. Bank Bukopin, Tbk. Branch of Padang.

3. Satisfaction on responsiveness has a significant effect on the loyalty of savings customers at PT. Bank Bukopin, Tbk. Branch of Padang.

4. Satisfaction on assurance has a significant effect on the loyalty of savings customers at PT. Bank Bukopin, Tbk. Branch of Padang.

5. Satisfaction on empathy has a significant effect on the loyalty of savings customers at PT. Bank Bukopin, Tbk. Branch of Padang. 


\section{Relevant research}

Previous research that is relevant is important for a study conducted because the results of previous research can be used as a reference for a prospective researcher in making a research hypothesis. (Putri, Naissy Susanti,2017) with the title of the thesis, namely: The Influence of Service Quality on Savings Customer Loyalty at Bank Sinarmas Padang Branch, where the results of the study found that tangibles, reliability, responsiveness, assurance and empathy had a positive and significant effect on the loyalty of Bank Sinarmas Branch savings customers Padang, where researchers used multiple regression analysis. The research conducted by (Efrizal,2013) with the title of the thesis, namely: The Influence of Satisfaction on the Dimensions of Bank Service Quality on Deposit Customer Loyalty at PT. Bank Negara Indonesia (Persero) Tbk. A Yani Padang Sub-Branch Office, the results showed that satisfaction with the dimensions of service quality (reliability, responsiveness, assurance, empathy and tangibles) had a significant effect on the customer loyalty of the BNI Bank A Yani Padang Branch where customers used multiple regression analysis.

Whereas in the Arzena study (2013) with the title of the thesis, namely: The Influence of Satisfaction on Service Quality and Trust in Customer Loyalty PT. Bank Mandiri, Tbk Muaro Padang Branch, obtained results that: (1) Satisfaction with service quality does not significantly influence customer loyalty of PT. Bank Mandiri Tbk Muaro Padang Branch and (2) Trust has a significant effect on customer loyalty PT. Bank Mandiri Tbk Muaro Padang Branch. In this study researchers used a multiple regression analysis test. Whereas the research was conducted (Abror, Evanita, \& Hidayat, 2012) with journal titles, namely: The Influence of Satisfaction on Service Quality and Brand Image on Garuda Indonesia Customer Loyalty in West Sumatra, the results of which were: (1) Satisfaction with the tangible significant to customer loyalty (2) Satisfaction with the dimensions of reliability has a significant influence on customer loyalty (3) Satisfaction with the dimensions of responsiveness does not have a significant effect on customer loyalty (4) Satisfaction with the assurance dimension has a significant effect on customer loyalty (5) Satisfaction with the dimensions of empathy does not have a significant effect on customer loyalty (6) Brand image has a significant effect on customer loyalty. In the journal using multiple regression analysis.

\section{Methods}

The object of this research was carried out at PT. Bank Bukopin, Tbk Branch of Padang to see the effect of satisfaction on the dimensions of service quality towards customer loyalty savings. This study includes satisfaction of tangible, satisfaction of reliability, satisfaction of responsiveness, satisfaction of assurance and satisfaction of empathy that affects customer loyalty at PT. Bank Bukopin, Tbk. Branch of Padang. Population is all customer savings accounts of PT. Bank Bukopin, Tbk. Branch of Padang, as many as 21,528 savings accounts.

The population amounted to 21,528 customer accounts, the researcher took samples according to the search results according to Slovin Formula with the results of 156 respondents with a trust level of $92 \%$ with a percentage of $8 \%$ error allowance. The sample technique used is Accidental Sampling method which according to (Sugiyono, 2015), accidental sampling is a technique of determining samples based on chance, that is, anyone who accidentally / incidentally meets with a researcher can be used as a sample, if viewed by people who coincidentally found it was suitable as a data source. The types and sources of data in this study use primary data and secondary data. Data collection techniques in this study were carried out through questionnaires and documentation. The instrument of this research was using questionnaires with a scale of Likert. Before the questionnaire is used, validity test and reliability test are first performed. From the validity test of all statements submitted, two invalid statements were issued. Furthermore, the data analysis technique in this study uses multiple regression analysis. then test the hypothesis $\mathrm{t}$ test and significant $\alpha=0.05$. 


\section{Result and Discussion \\ Result}

Before using multiple regression analysis, the classical assumption test was carried out, namely the analysis prerequisite test in the form of normality test, heteroscedastity test and homogeneity test. From the normality test results obtained that the data is normally distributed, then from the heteroscedastity test obtained the results of heteroscedasticity tests are fulfilled and free from heteroscedasticity test, from the results of homogeneity test it is concluded that the variables are homogeneous.

From the three pre-analysis test results above, the research can be continued using multiple regression analysis. As a statistical tool, regression is useful in answering research questions (formulation of the problem) as follows: "How far the variation in changes in the dependent variable can be explained by all independent variables both together, or partially (individually)". In the correlation analysis of the position of equivalent variables, while in the regression position the variables are not equal, there are dependent variables and there are independent variables. (Idris, 2013). Analysis is carried out with the SPSS 16 application. The results of multiple analysis can be seen in Table. 3 as follows:

Table 3 Results of Multiple Regression Analysis

\begin{tabular}{lrrrl}
\hline \multicolumn{1}{c}{ Variable } & $\begin{array}{l}\text { Regression } \\
\text { Coefficient }\end{array}$ & $\mathbf{t}$ & Sig. & Information \\
\hline Constanta & 5,708 & 3,705 & 0,000 & \\
\hline $\begin{array}{l}\text { Satisfaction of } \\
\text { Tangibles }\end{array}$ & 0,281 & 3,466 & 0,001 & Significant \\
\hline $\begin{array}{l}\text { Satisfaction of } \\
\text { Reliability }\end{array}$ & 0,421 & 4,275 & 0,000 & Significant \\
\hline $\begin{array}{l}\text { Satisfaction of } \\
\text { Responsiveness }\end{array}$ & 0,047 & 0,625 & 0,533 & No significant \\
\hline $\begin{array}{l}\text { Satisfaction of } \\
\text { Assurance }\end{array}$ & 0,037 & 0,443 & 0,658 & No significant \\
\hline $\begin{array}{l}\text { Satisfaction of } \\
\text { Empathy }\end{array}$ & $-0,044$ & $-0,575$ & 0,566 & No Significant \\
\hline source: processing primary data (2018) & & &
\end{tabular}

source: processing primary data (2018)

Based on the results of multiple analysis it can be describe the estimation model is obtained as follows: $Y=5,708+0,281 X_{1}+0,421 X_{2}+0,047 X_{3}+0,037 X_{4}-0,044 X_{5}+e$, Based on the above equation it can be explained that:

1. There is a constant value of 5.708 which means that if satisfaction on tangibles, reliability, responsiveness, assurance and empathy is zero (0), then the variable value of customer loyalty is at 5,708 . This indicates that the satisfaction variable on the dimensions of tangibles, reliability, responsiveness, assurance contributes to increasing customer loyalty, while satisfaction with empathy actually decreases customer loyalty.

2. Regression coefficient of customer satisfaction for tangibles is positive 0,281 . This means that if customer satisfaction with physical evidence increases by one unit, it will result in an increase in customer loyalty of 0,281 units.

3. Regression coefficient of customer satisfaction for reliability is positive 0,421 . This means that if customer satisfaction with reliability increases by one unit, it will result in an increase in customer loyalty of 0,421 units.

4. Regression coefficient of customer satisfaction on responsiveness is positive 0,047 . This means that if customer satisfaction over responsiveness increases by one unit it will result in an increase in customer loyalty by 0,047 units.

5. Regression coefficient of customer satisfaction on collateral is positive 0,037 . This means that if customer satisfaction over responsiveness increases by one unit it will result in an increase in customer loyalty by 0,037 units. 
6. Regression coefficient of customer satisfaction over empathy is negative 0,044 . This means that if customer satisfaction over responsiveness increases by one unit it will result in a decrease in customer loyalty by 0,044 units.

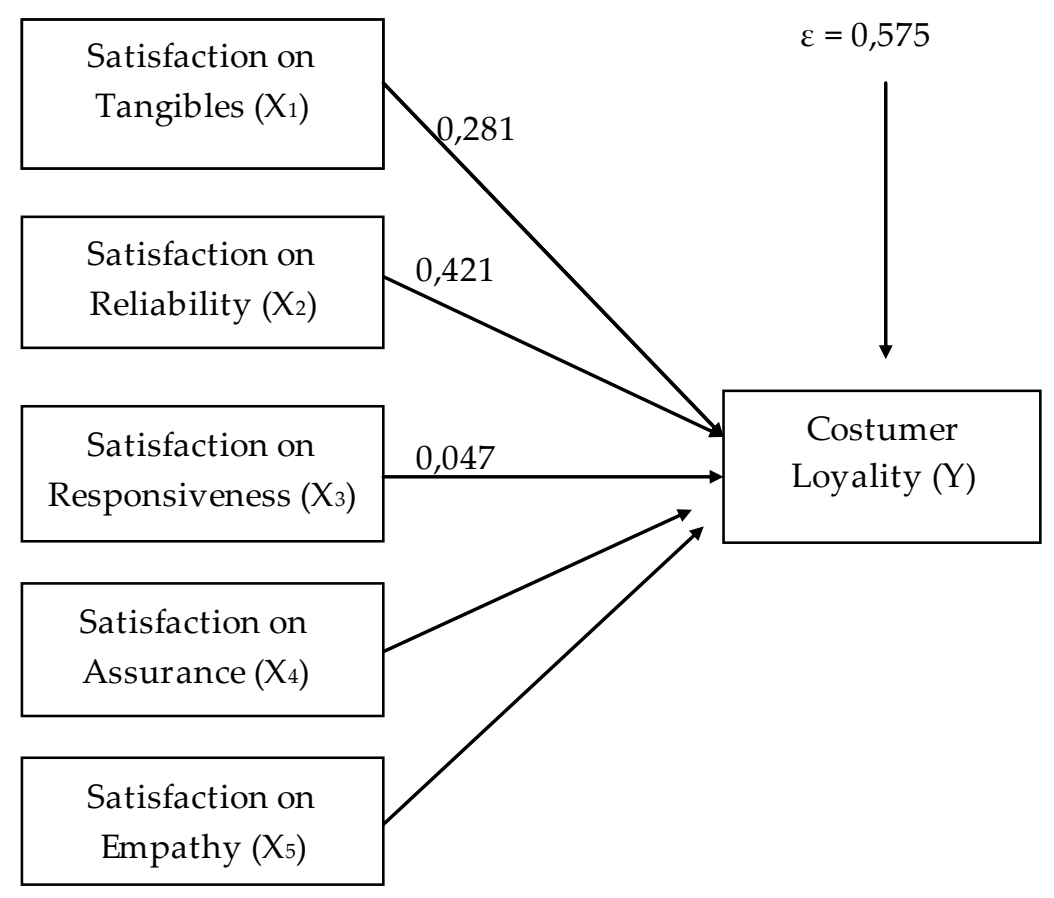

Figure 2 Results of Multiple Regression Analysis

The characteristics of the respondents of Bank Bukopin's customers by sex are women with an age range between 31 to 40 years with a majority of jobs as civil servants and the last level of education is a diploma. Most of the customers saving between 1 to 5 years with the majority of customer savings are Savings Savings. Based on the respondent's characteristics, PT. Bank Bukopin, Tbk. Branch of Padang really needs to pay attention that its customers have more women, so Bank Bukopin is advised to make programs that can attract female customers such as direct savings programs such as shopping vouchers, gadgets, tools and kitchen utensils such as tupperware, lock and lock prizes, holiday vouchers and others. Based on the longer characteristics of saving more customers between 1 and 5 years, Bank Bukopin Branch of Padang needs to increase savings products that can bind customers to save up to more than 5 years as well as the Bukopin Savings Plan products such as time savings for the future of children's education. The longer the customer saves, the more loyal the customer is to Bank Bukopin.

The average score of customer satisfaction for tangibles is 4.00 , satisfaction with reliability 4.02 , satisfaction with responsiveness 4.05 , satisfaction with guarantees 4.22 and satisfaction with empathy 4.08. This shows that the respondents were satisfied with the services provided by PT. Bank Bukopin, Tbk. Branch of Padang. Of the five dimensions of service quality, satisfaction with tangibles shows the lowest score and satisfaction with guarantee shows the highest score.

\section{Discussion}

Effect of satisfaction on Tangibles toward Loyality of Savings Customers at PT. Bank Bukopin, Tbk. Branch of Padang

From the results of the study, it can be seen that the satisfaction variable for physical evidence has a coefficient of 0.281 with a sig value. $0.001<0.05$, which means that satisfaction on tangibles has a positive and significant effect, so satisfaction on tangibles plays a role in increasing customer loyalty at PT. Bank Bukopin, Tbk. Branch of Padang. Why is that? Because according to the customer, 
satisfaction with tangibles is one of the determining factors that makes customers loyal, if the customer is satisfied with physical evidence such as a magnificent building, a clean and comfortable room, a spacious parking area and a large and smooth ATM machine will make customers satisfied and loyal to a bank. This means that the higher customer satisfaction with the physical evidence available at PT. Bank Bukopin, Tbk. Branch of Padang will increase customer loyalty at PT. Bank Bukopin, Tbk. Branch of Padang.

The results of research at PT. Bank Bukopin, Tbk. Branch of Padang which shows that satisfaction on tangibles influences customer loyalty is in line with the theory carried out by Parasuraman in Tjiptono (2011), because the performance of services is intangible, tangible provides guidance on service quality and in some cases greatly affects customers in assessing these services, so it needs to be carefully considered the nature of tangibles for customers. The statement is in accordance with the results of the research conducted, a good bank appearance that will make loyal customers. Parasuraman et al in Tjiptono (2011) suggested tangibles, including the availability of physical evidence in services such as physical facilities. Tangibles is a factor that looks like a clean room and a variety of well-functioning facilities and various other facilities and tools that function properly. This illustrates the ability of a company in this case the bank in showing its existence to external parties.

This opinion is also in line with the research conducted by Putri (2017) which states that tangibles have a positive and significant effect on customer loyalty at the Padang branch of Bank Sinarmas. This opinion is also in accordance with the research conducted by Efrizal (2013) which states that satisfaction with the dimensions of physical evidence has a positive and significant effect on customer loyalty to Bank BNI deposits at the branch of A. Yani Padang. The better satisfaction with tangibles (physical evidence), the more loyal customers will be.

\section{Effect of Satisfaction on reliability toward Loyalty of Savings Customers at PT. Bank Bukopin Branch of Padang}

The results of this study indicate that the variable satisfaction on reliability has a coefficient of 0.421 with the value of Sig. 0,000<0,05 means that satisfaction on reliability has a positive and significant effect on customer loyalty at PT. Bank Bukopin, Tbk. Branch of Padang. Why is that? Because according to the customer, satisfaction on reliability is one of the factors that makes customers loyal, such as the ability of banks to perform services that are rightly promised, fast and accurate and have the sophistication of ATM features and network connections. If this is fulfilled, the customer will be satisfied and loyal.

The results of this study are in line with the theory expressed by Johnstone \& Silvestra (1990) in Tjiptono \& Chandra (2010: 135), reliability is service attributes that are absolutely necessary to create a perception of good or positive service quality. The absence or inaccuracy of this factor will lead to negative perceptions of service quality, but if this factor is increased it will continue to have a positive impact on customer perceptions.

Satisfaction on reliability has a positive and significant influence, this is in line with research conducted by Putri (2017) which states that reliability affects customer loyalty at the Padang Branch of Bank Sinarmas. This opinion is in line with the research conducted by Efrizal (2013) which states that satisfaction with the dimensions of reliability has a positive and significant effect on customer loyalty to Bank BNI deposits at the A. Yani Padang branch. The better satisfaction with reliability will increase the loyalty of bank customers.

\section{Effect of Satisfaction on Responsiveness toward Loyalty of Savings Customers at PT. Bank Bukopin Branch of Padang}

The results of this study show different results, where the satisfaction on responsiveness has a coefficient of 0.047 with Sig. $0.533>0.05$ means that satisfaction on responsiveness does not significantly influence the loyalty of savings customers at PT. Bank Bukopin, Tbk. Branch of Padang. Why is that? Because customers feel satisfaction with responsiveness is not too important because there is already a standard from Bank Indonesia. Nearly every standard bank, service satisfaction for responsiveness is almost the same as in terms of availability in helping quickly and precisely, 
availability in providing immediate service, responding to requests and speeding up in solving problems provides solutions.

Satisfaction on responsiveness does not have a significant effect on customer loyalty, this is in line with research conducted by Arzena (2013) which says that satisfaction with service quality on responsiveness variables does not significantly influence customer loyalty of PT. Bank Mandiri, Tbk. Muaro Padang Branch. As for Syamsul, Yessi (2017) in Padang Pariaman Hospital, which states that satisfaction with patient responsiveness to RSUD (Regional Public Hospital) Pariaman does not affect loyalty.

This is contrary to the theory of Tjiptono (2011) which says that customer satisfaction has an effect on customer loyalty. This proves that the responsiveness variable in Bank Bukopin's service is not a measure for customers to be loyal or not. According to Tjiptono (2011) one aspect that is used to handle complaints is the speed at which complaints are dealt with. In this case if the customer complaint is not quickly responded to, it is feared that loyalty will decrease. It can be concluded that if a bank is not responsive to its customers, the bank will not get loyal customers. This is contrary to research carried out on savings customers at PT. Bank Bukopin, Tbk. Branch of Padang.

4. Effect of Satisfaction on Assurance toward Loyalty of Savings Customers at PT. Bank Bukopin Branch of Padang.

The results of this study show different results, where the satisfaction variable on assurance has a coefficient of 0.037 with Sig. $0.658>0.05$ means that satisfaction on assurance does not significantly influence the loyalty of savings customers at PT. Bank Bukopin, Tbk. Branch of Padang. Why is that? Because customers feel that each bank has provided guarantees and good security standards in safeguarding customer data, finances and secrets.

This is in line with the research conducted by Arzena (2013) which says that satisfaction with service quality on the assurance variable does not significantly influence the customer loyalty of PT. Bank Mandiri, Tbk. Muaro Padang Branch. As for the results of Syamsul's research, Yessi (2017) in Padang Pariaman Hospital which states that patients come for treatment not because of loyalty but because of compulsion. This finding proves that the guarantees provided by banks will not affect customer loyalty.

This is contrary to the theory of Parasuraman et al (1988) in Tjiptono (2011) which concluded that the guarantee variable included in service quality has a significant relationship and influence on loyalty. On the other hand Lupiyoadi (2010:182) states that guarantee or certainty is the knowledge, politeness and ability of company personnel to foster customer trust in the company.

\section{Effect of Satisfaction on Empathy toward loyality of Savings customers at PT. Bank Bukopin} Branch of Padang.

The results showed different results, where the satisfaction variable on empathy has a coefficient of -0.044 with Sig. $0.566>0.05$ means that satisfaction on empathy does not significantly and negatively affect the loyalty of savings customers at PT. Bank Bukopin, Tbk. Branch of Padang. Why is that? Because customers feel satisfaction with empathy is not too important and there are standards that are the same as every bank.

This shows that the size and size of the empathy coefficient does not affect customer loyalty. This is in line with the research conducted by Arzena (2013) which says that satisfaction with service quality on empathy variables does not significantly influence customer loyalty of PT. Bank Mandiri, Tbk. Muaro Padang Branch. Syamsul's research, Yessi (2017) states that satisfaction with empathy does not affect patient loyalty in Padang Pariaman Hospital. This is in line with the results of Nasution's research, (2017) which states that the dimensions of service quality as measured by empathy have no significant effect on customer service in the Bay Bayur Port Branch Business Division.

This is contrary to the theory presented by Mowen and Minor (2002), Helgesen and Nesset (2007), Brunnet.al (2008) in Abrar's research, Evanita and Hidayat, (2013) who found that customer satisfaction had an effect on customer loyalty, namely including contact personnel and improving 
relationships which are forms of empathy that can be given to customers so that they can make customers satisfied and become loyal customers.

\section{Conclusion}

Based on the results of the research and discussion, that satisfaction on the dimensions of service quality influences customer loyalty, but not all parts of the quality dimension affect customer loyalty. Only satisfaction on tangibles and reliability has a significant effect on customer loyalty at PT. Bank Bukopin Branch of Padang. Satisfaction on reliability has the most high influence for customer loyality.

The results of this study are expected to be useful and contribute for the author, as one of the conditions for obtaining a Master of Management degree in the Faculty of Economics, Universitas Negeri Padang, For PT. Bank Bukopin Branch of Padang, as information and future reference in an effort to increase customer loyalty. From the research shown PT. Bank Bukopin, Tbk. Branch of Padang must increase the satisfaction on reliability and satisfaction on tangibles for customer loyality and for the study of Marketing Management science, so that it can be used as a reference for the development of research, especially the study of Marketing Management and banking science in the future.

The limitation in this study is to focus on the influence of satisfaction on the dimensions of service quality on customer loyalty, this study is very important to read and study because to know the extent to which satisfaction with the quality dimension affects customer loyalty in a bank and relevance to the times. So that future research is expected to increase the influence of other variables such as value variable and brand variable on customer loyalty, then research can be done at several branches of PT. Bank Bukopin, Tbk in West Sumatra and coverage per region.

\section{References}

Abror, Evanita, S., \& Hidayat, K. (2012). Pengaruh Kepuasan Atas Kualitas Pelayanan dan Citra Merek Terhadap Loyalitas Pelanggan Garuda Indonesia di Sumatera Barat. Jurnal Kajian Manajemen Bisnis Volume 1, Nomor 1, Maret 2012 Pengaruh, 1(2005), 32.

Agrawal, R., Gaur, S. S., \& Narayanan, A. (2013). Determining customer loyalty: Review and model. ${ }^{*}$ Correspondence Details and Biographies for the Authors Are Located at the End of the Article. The Marketing Review, 2012, Vol. 12, No. 3, Pp. 275-289

Asmawati, H. (2018). Strategi Pengembangan Usaha Dengan Metode Analisis Swot Pada Usaha Laundry. EJournal Administrasi Bisnis, 2018, 6 (1): 65-76 ISSN 2355-5408, Ejournal.Adbisnis.FisipUnmul.Ac.Id, 6(1), 65-76.

Hasan, Ali. (2010). Marketing. First print. Yogyakarta: Medpress.

Hasan, M. Iqbal. (2010). Subjects of Statistics 1 (Descriptive Statistics). Jakarta: Earth alphabet.

Hidayat, C. (2016). Pengukuran Orientasi Pasar pada Jenis Usaha Mikro, Kecil, dan Menengah. Binus Business Review, 6(2), 250. https://doi.org/10.21512/bbr.v6i2.974

Huda, Ahmad Nurul and Sri Wahyuni. (2013). Analysis of the Effect of Internet Banking Service Quality and Satisfaction Level on Customer Loyalty at PT Bank Rakyat Indonesia (Persero) Tbk Jakarta Social Security Branch Office. Journal Business \& Management.

Hurriyati. (2010). Customer Satisfaction. Sixth print. Jakarta: PT. Elex Media Computinda.

Idris. (2013). Application of Quantitative Data Analysis Model with SPSS Program. Revised Edition III. Padang: Faculty of Economics - Universitas Negeri Padang.

Khasmir. (2010). Pengantar Manajemen Keuangan.Jakarta: Kencana Prenada Madia Group.

Khasmir. (2014). Banking Management. Revised Edition. Jakarta: PT. RajaGrafindo Persada.

Khan, O. (2016). Loyalty Pyramids: A New Paradigm In Services Loyalty. International Journal of Finance and Management, 1(March).

Laškarin, M. (2013). Development of Loyality Programmes. Tourism and Hospitality Management, Vol. 19, No. 1, Pp. 109-123, 2013, 19(May 2013), 109-123.

Lupiyoady, Rahmad. (2010). Service Marketing Management. Jakarta: Salemba Empat. 
Setiaji, Y. (2014). Pengaruh Green Marketing Terhadap Keberlanjutan Lingkungan, Profitabilitas Perusahaan Dan Ekonomi Masyarakat Lokal. Jurnal Media Wisata, Volume 12, Nomor 2, November 2014, 12(2), 116-138.

Sugiyono. (2015). Statistics for Research. Bandung: CV. Alfabeta.

Widodo, S. (2018). Pengaruh Kualitas Pelayanan Terhadap Loyalitas Pelanggan Pada Ahad Mart Cinere. Manajemen Pemasaran ISSN NO. (PRINT) 2598-0823, (ONLINE) 2598-2893, 1(3). 